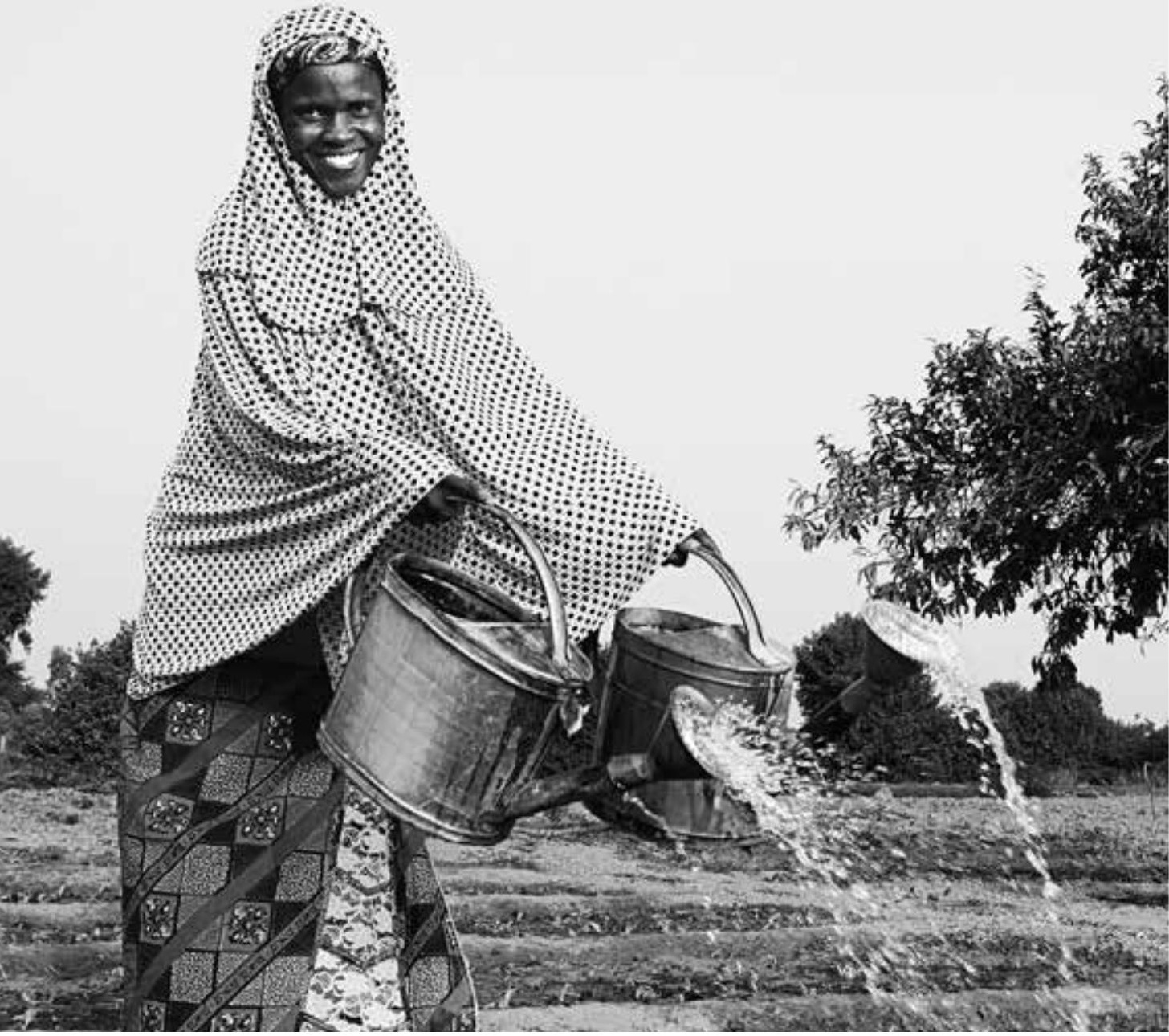

AIBR

Revista de Antropología

Iberoamericana

www.aibr.org

Volume 16

Number 1

January - April 2021

Pp. $17-36$

Madrid: Antropólogos

Iberoamericanos en Red.

ISSN: 1695-9752

E-ISSN: 1578-9705

\section{The Art of Ethnography in Troubled Times}

Paul Stoller

West Chester University

Submitted: July 27, 2020

Accepted: November 15, 2020

DOI: 10.11156/aibr.150203e 


\section{ABSTRACT}

Many of our longstanding set of methods and denotative conventions of representation are no longer in harmony with the state of contemporary social, political, environmental and economic dysfunction. How can we create a representation that goes beyond the academic communication in a troubled world? How can we create "stories", which work as the glue that holds people together, in order to connect with them? This is the basic question in the Art of Ethnography, an idea that begins with Maurice Merleau-Ponty's, in his essay Eye and Mind. This piece suggests that the work of art is a pathway to an embodied enlightenment that can enable us to practice what Michael Jackson has called "the art of life". It is the result of several aspects. For example, space and place, which are alive with memory, or dialogue, which is a window into personality of the characters, since it defines the people we study and makes them particular. This is a moment of troubled times, but also a moment of adaptation to our modes of representation, and an opportunity to develop the Art of Ethnography.

KEY WORDS

Arts, Ethnography, troubled times, life.

\section{EL ARTE DE LA ETNOGRAFÍA EN TIEMPOS TURBULENTOS}

\section{RESUMEN}

Muchos de nuestros métodos clásicos y de las convenciones de representación han quedado desfasados con la situación disfuncional social, política, ambiental y económica de nuestros tiempos. ¿Cómo podemos crear una representación que vaya más allá de la comunicación académica en un mundo turbulento? ¿Cómo podemos crear las «historias», lo que mantiene unida a la gente, para poder conectar con ella? Esta es la pregunta de partida en El arte de la Etnografía, una idea que comienza con el texto Eye and Mind, de Maurice MerleauPonty. Este ensayo sugiere que la obra de arte es una manera de alcanzar una forma ilustrada de aquello que Michael Jackson llamó «el arte de la vida». Nos llega a través de la combinación de varios aspectos. Por ejemplo, del espacio y el tiempo, que están vivos en la memoria de las cosas, o el diálogo, que es una ventana a la personalidad de los personajes y les hace ser especiales. Vivimos tiempos turbulentos, pero también tiempos de adaptación en nuestros modos de representación, y esto supone una oportunidad de desarrollar el arte de la Etnografía.

PALABRAS CLAVE

Arte, Etnografía, tiempos turbulentos, vida. 
In May of this year gunmen riding on motorcycles looted shops, stole cattle and killed 20 people in the Tillaberi Region of Niger - the latest in a two-year cycle of Al Qaeda-inspired violence. This news filled me with sadness. Having spent many years in Tillaberi I harbor wonderful memories of gracious and dignified people, of sweeping vistas of the Niger River snaking its way through majestic dunes and sandstone buttes, and of hunger-inducing aromas of kabobs cooking on makeshift grills. My teacher, Adamu Jenitongo, lived in a dune-top compound in Tillaberi, the site of many compellingly beautiful traditional religious rituals. What had once been social life characterized by widespread tolerance has been replaced with religious zealotry.

The dysfunction that has shredded the social fabric in Tillaberi, Niger is, of course, not an isolated phenomenon. These days we live in world in which we can no longer ignore systemic racism, ethnic discrimination, religious intolerance, and income inequality, not to forget the social and economic devastation of the coronavirus pandemic.

How can anthropologists meet the challenges of our troubled times?

In this lecture I suggest that we confront our obligations as scholars and admit that many of our longstanding set of methods and denotative conventions of representation are no longer in sync with the state of contemporary social, political, environmental and economic dysfunction. In the coming months

Will we be able to pay our bills, our rents, and our mortgages?

Will we be able to feed our children and keep them safe?

Will the covid-19 virus infect our loved ones? And if it does, will we survive?

In anthropology we know a great deal about these existential issues, but because of our reliance on established conventions of representation, our insights have often had admittedly limited appeal. To meet the existential challenges of contemporary times, I propose that anthropologists plunge into the art of ethnography, in which ethnographers sensuously articulate dimensions of locality, language, and character. Borrowing techniques from film, poetry, and fiction, artfully inspired ethnographers can craft ethnographic narratives in text and film that can connect the public to the idiosyncrasies of people and place. In so doing, I argue, an artful ethnography has the potential to bring to the public sphere a nuanced wisdom of others, the very foundation of anthropological insight. Such wisdom can set a course that ultimately leads to meaningful change and social justice. In our current circumstances I may only be able to do virtual fieldwork in Tillaberi and New York City, but I, like all anthropolo- 
gists, can work to produce artful ethnography that showcases the inspirational resilience of human beings in the world.

\section{Eye and Mind}

For me, the art of ethnography beings with Maurice Merleau-Ponty's brief text, Eye and Mind is undisputedly one of the most influential philosophical essays of the $20^{\text {th }}$ century. In it, the great phenomenologist suggests that the work of art is a pathway to an embodied enlightenment that can enable us to practice what Michael Jackson (2016b) has called "the art of life." The key premise Eye and Mind is that nature, as the artist Paul Cézanne suggested, is on the inside. To know nature, then, is to know the texture of inner space. As Merleau-Ponty (1964: 22) wrote: the "quality, light, color, and depth which are there before us are there only because they awaken an echo in our body and because the body welcomes them." Such an orientation is a critique of scientific positivism. For MerleauPonty and Cézanne there is an inner reality of things that supplements the "objective" reality that scholars have extracted from their observations of the world. To operationalize this inner reality into hypotheses, formulae, and laws condemns us to a superficial apprehension of the physical and social worlds. Merleau-Ponty believed that the painter is our guide on the path to what he called the "there is." The painter savors the life that resides in the inner dimensions of things. Indeed, the painter, like other artists, feels the "reverberations" that can create awareness in the eye and mind of the person who confronts the sensory splendor of the world.

Merleau-Ponty's writing about art is not some vague mystical journey into the unseen or the sensory unconscious. In Eye and Mind, he suggests that artists are our guides to the "there-is" because they open their being to the world. "Indeed, we cannot imagine how a mind could paint. It is by lending his body to the world that the artist changes the world into paintings" (Merleau-Ponty 1964: 16). Put another way, the act of painting is a metaphor for sensing the world from the inside. This idea is underscored by the great Swiss-born painter Paul Klee whose lectures on art and design were published in The Paul Klee Notebooks in which the great artist wrote:

In a forest I have felt many times over that it was not I who looked at the forest. Some days I felt that the trees were looking at me. I was there, listening... I think that the painter must be penetrated by the universe and not penetrate it... I expect to be inwardly submerged, buried. I paint to break out (Charbonnier, 1959, cited in Merleau-Ponty, 1964: 31). 
Are artists alone in their inner sensibilities? Merleau-Ponty charts a course toward a sensuous turn in our observations and our representations of those observations. Such a turn, of course, can be applied to anthropologists and their representations. How do we make the indeterminacies of existence intelligible? How can we bring them to life? Consider Nietzsche's thoughts on scientific intelligibility. He wrote that the mission of science

Is to make existence intelligible and thereby justified... Socrates and his successors, down to our day, have considered all moral and sentimental accomplishments - noble deeds, compassion, self-sacrifice, heroism... to be ultimately derived from the dialectic of knowledge and therefore teachable... But science, spurred on by its energetic notions, approaches irresistibly those outer limits were the optimism of logic must collapse... When the inquirer, having pushed to the circumference, realizes how logic in that place curls about itself and bites its own tail, he is struck with a new kind of perception, a tragic perception, which requires, to make it tolerable, the remedy of art (1956: 93).

By way of Nietzsche, Cézanne, and Klee Merleau-Ponty suggested that scholarly discourse is limited. Denotation or telling has a limited capacity to describe the inner dimensions of nature or the deep recesses of the human existence. The deep exploration of the human condition requires, for MerleauPonty, the remedy of art (evocation or showing). Indeed, Merleau-Ponty has much to say about the power of evocation in art and in artful prose.

\footnotetext{
The words, the lines and the colors which express me come from me as my gestures are torn from me by what I want to say, the way my gestures are and by what I want to do... In the art of prose, words carry the speaker and listener into a common universe by drawing both toward a new signification through their power to designate in excess of their accepted definition (Merleau-Ponty, 1964b: 139).
}

Merleau-Ponty (1969:20) goes on to suggest that the... "words most charged with philosophy are not necessarily those that contain what they say, but rather those that most energetically open upon being, because they more closely convey the life of the whole and make our habitual vibrate until they disjoin." In this way, writers - or painters, for that matter use what Merleau-Ponty calls "the indirect voice" to evoke the "brute and wild being" of the world.

\section{Experience and The Work of Art}

As my summary of the political, social and cultural instability in Tillaberi, Niger suggests, we live in complex and unstable times. There are no quick- 
fix answers to the political, social, and intellectual problems of the current era. Given the multiplex whys and wherefores of contemporary life, is it still possible to make sense of the human condition? Can we apprehend Merleau-Ponty's brute and wild being? And if we can experience such a revelatory and brute consciousness, will it deepen our sensibilities, our capacity to understand the imponderables of living in the world? Do artists and anthropologists have a role to play in this important contemporary endeavor? What can Merleau-Ponty's Eye and Mind teach us about confronting the darkness that has swept over contemporary social life? Can we squeeze small measures of wellbeing from the speedy chaos of social life? Can anthropological insight chart a path that leads to a life well-lived? In two of Michael Jackson's latest books - one on reinventing philosophical anthropology and one on the power of art in shaping the contours of social life, the anthropologist-poet explores these vexing questions with powerful perspicacity.

In As Wide as the World is Wise, Jackson (2016a) elegantly explores the spaces between things - murky spaces in which human beings are always already, to borrow from Jacques Derrida, situated. These are spaces that escape brute categorization. They are spaces that are defiantly non-concrete - spaces that require the evocation of art and artful scholarship. For his epigraph, Jackson quotes Jacques Derrida.

The logocentrism of Greek metaphysics will always be haunted... by the "absolutely other" to the extent that the Logos can never englobe everything. There is always something which escapes, something different, something other and opaque which refuses to be totalized into a homogeneous identity (Derrida, 1984: 117).

In this wonderfully crafted work, Jackson is our guide to those existential spaces in which, according to Nietzsche "logic curls up and bites its own tail.” These are spaces that are different and opaque. After more than 40 years of fieldwork in West Africa and Australia, after a lifetime of reading, reflection, and writing about living-in-the-world, Jackson describes how his experience directed him to follow the sinuous, non-totalizing path between things - between the one and the many, between identity and difference, between ourselves and others, between the personal and the professional, between belief and experience, between being and thought, between fate and freewill, between center and periphery. As Wide as the World is Wise, then, is a book that artfully explores the imaginative spaces between anthropology and philosophy. Indeed, in this rich, deep, and textured book Jackson's erudition demonstrates with eloquence 
how the messy specificity that characterizes ethnography enriches our thought. Consider this thought-provoking passage:

Are philosophy and anthropology not also ways of creating appearances whether of order and understanding - that provide us with a sense of purchase on the elusive face of human existence? And are not philosophers and anthropologists the cousins-german of the trickster heroes who figure in all traditions? (2016a: 50).

Indeed, Jackson provides a plethora of ethnographic and experiential examples that demonstrate how our anthropological and philosophical cogitations "never englobe everything," to return yet again to Derrida (1984). “There is always something that escapes...” (Jackson, 2016a: 117). Things are always impermanent. Our experience, feelings, thoughts are continuously evolving. Our lived reality is one that confounds everyday certainty. We are all in "the between." In life, we find ourselves in

\footnotetext{
[...] a perpetual oscillation between engaging with the world and seeking distance, respite, or release from it. No matter what vernacular idiom is employed to capture this oscillation - philosopher's hut, the open field, the contrast between town and bush, theological images of earth and ether, existential tensions between home and the world - the dilemma persists of how to balance and reconcile these competing imperatives, or discover how one can live with their incommensurability (2016a: 204).
}

How can we live in the intellectual and experiential turbulence of "the between?" How can we bear the intellectual and existential fruits of cultivating what Keat's called "negative capability," the capacity to live with incommensurability, the inchoateness of which stretches the imagination and sparks creativity?

Jackson considers these questions in another recent work, The Work of Art (2016b), in which he rethinks Durkheim's The Elementary Forms of Religious Life (1995) from a decidedly phenomenological perspective. Drawing inspiration from the aforementioned Eye and Mind (MerleauPonty, 1964), Jackson tacks between personal reflection and an interpretation of a varied group of artists, including the mesmerizing productions of Australian Aboriginal artists. By way of his analysis and his personal reflections, Jackson demonstrates how art is not an inert element of representation but a dynamic force that can transform life. The work of art, then, can enable us to open our being to the world, prompting writers and painters to see-think from the inside.

In the end, Jackson extends his analysis of artistic works to write about the art of life. 
[...] The art of life is thus an art of making the world appear perennially new by what Rimbaud called "un long, immense et raisonne dereglement de tous sens" - an endless play of light and dark, bitter and sweet, sound and silence, hard and soft, acrid and fragrant. Against the grain of inscribed habits of thought, action, and perception, art — whether graphic, sculptural, musical, verbal, gestural or kinesic — involves a honing, a practicing, a play of our sensibilities, which bring us to a place that seems to surpass the familiar, the known, the expected, surprising us, taking our breathe away, opening our eyes, transforming our understanding, and, ultimately, re-creating ourselves (2016b: 186).

Between the lines of this book, Jackson demonstrates that art can transport us to the creative and imaginative spaces between things. $\mathrm{He}$ shows us how art can reshape our being in the world, transforming our inner turmoil into the outward beauty of prose, poetry, drama, sculpture, and painting - works that move us.

\section{The Art of Ethnography}

Can anthropologists, most of whom have conducted extensive ethnographic research, follow obscure tracks the criss-cross the deserts of academic discourse and find illumination? Can we, following the embodied insights of Merleau-Ponty's Eye and Mind and the wisdom found in Michael Jackson' The Work of Art, embrace the art of ethnography? In the end, can we learn how to convey to the public our important and slowly developed insights about the human condition?

Many scholars reduce ethnography to a set of practices. Ethnographers, after all, conduct fieldwork in a variety of settings. Fieldwork consists of Malinowski's celebrated, if not conceptually flawed, notion of participant observation - "being there." Trying to observe while you participate is no easy feat. Even so thousands of ethnographers have attempted this oxymoronic method as they struggle to conduct a census, engage in informal and semi-formal interviews, or attend a ritual which they may photograph or film. In the same vein, ethnographers are supposed to record their participant-observations in fieldnotes, some purely observational, some more personal. These fieldnotes combined with field photographs and field films become the foundation for constructing a representation. In the end these ethnographic texts or films contribute to the ethnographic record. Is this not the set of procedures that we teach our graduate students?

Beyond the rigorous set of rules that define ethnographic research, the potential distinctiveness of ethnographic texts often gets lost in the fog 
or institutional expectation. The "expected" anthropological monograph should have an introduction, a review of the relevant literature, presentation of data, a discussion of the data and a conclusion in which the work's disciplinary significance, which the author has stated in the introduction, is reaffirmed. These academic conventions of representation more often than not lead to the production of turgid texts of limited appeal. Given the economic privations of contemporary publishing publishers now have a less than enthusiastic interest in publishing anthropological works.

One way to change this representational dilemma is to engage in the art of ethnography, in which writers sensuously articulate dimensions of locality, language, and character. Borrowing the thoughts of MerleauPonty and techniques from film, poetry, and fiction, artfully inspired ethnographers can craft ethnographic descriptions such that readers come to know the dynamic idiosyncrasies of the people and place. In so doing an artful ethnography has the potential to spread slowly developed important anthropological insights far and wide.

\section{Space and Place in Artful Ethnography}

An artful ethnography can bring to life ethnographic spaces and places. It can give readers a sense of locality - one of the great gifts that ethnography brings to the world. How can writers use words to sensuously describe a landscape, a wall, a road, a house, or a room. For me, writers should try to describe a space or place as if it were alive - with feelings and memories. As strange as it may seem, writers should attempt to let the sights, smells, sounds, texture of a space/place dictate how to describe it. This technique borrows from Paul Klee's aforementioned technique of opening his being to the forest and painting it to "break out." In this painterly style of describing ethnographic spaces, it is important to highlight salient features. It is also important to imagine what a particular room, house, tree, or pathway has witnessed. When I recently observed a majestic baobab tree, which grows next to the Institute of African Studies at the University of Ghana, Legon, I wondered what history that tree had witnessed?

Sensuously setting an ethnographic scene can captivate readers, compelling contemporary readers to turn the page. Here are some examples in which writers evoke space and place. Consider how James Agee, author of Now Let Us Praise Famous Men (Agee y Evans, 1941), an ethnography of life in rural Alabama during the American Depression, described a sharecropper's house. 
Every few minutes George would get up and open the door a foot or so, and it showed always the same picture; that end of the hallway mud and under water, where the planks lay flush to the ground; the opposite wall; the open kitchen; blown leaves beyond the kitchen window; a segment of the clay rear yard where rain beat on rain beat on rain beat on rain as would beat out the brains of the earth and stood in a bristling smoky grass of water a foot high... (1941: 365).

A more contemporary example of sensuous ethnographic scene setting comes from Anna Badkhen and her 2018 work of creative non-fiction, Fisherman's Blues: A West African Community at Sea. Follow how Badkhen describes a dawn at sea near Joal, Senegal's largest "artisanal" fishing port.

Dawn spills astern: lavender, violet, golden. Capillary waves gently scale the ocean all the way to the horizon. Winds clots low fog. The Sakhari Souare glides at full throttle west-southwest, rolls over lazy six-foot swells. The shore's low skyline of baobab, eucalyptus and doum palm flashes in the light, sinks into the sea. Its bruised cumulus vanishes, too. Black against the banded east, a seabird, an early riser, falls out of the fog and scoops something out of the water and banks away. The pirogue's six crew balance spreadeagled on the thwarts and on the foredeck, dig their bare soles into the slippery wood, learn into one another, watch the sea for fish (2018, 1-2).

Here's how I attempted to sensuously set the scene for my ethnography of Songhay spirit possession, Fusion of the Worlds (Stoller, 1989):

Clack! A sharp sound shattered the hot, dry air above Tillaberi. Another clack, followed by a roll and another clack-roll-clack, pulsed through the stagnant air. The sounds seemed to burst from the dune that overlooked the secondary school of the town of a thousand people, mostly Songhay-speaking, in the Republic of Niger.

The echoing staccato broke the sweaty boredom of a hot afternoon in the hottest town in one of the hottest countries in the world and, like a large hand, guided hearers up the dune to Adamu Jenitongo's compound to witness a possession ceremony.

The compound's three-foot millet stalk fence enclosed Adamu Jenitongo's dwellings: four straw huts that looked like beehives. At the compound's threshold, the high-pitched whine of the monochord violin greeted me. Inside, I saw the three drummers seated under a canopy behind gourd drums. Although the canopy shielded them from the blistering Niger sun, sweat streamed down their faces. Their sleeveless tunics clung to their bodies; patches of salt had dried white on the surface of their black cotton garments. They continued their rolling beat. Seated behind them on a stool was the violinist, dressed in a red shirt that covered his knees. Despite the intensity of the heat and the noise of 
the crowd, his face remained expressionless as he made his instrument "cry" (1989: 1).

The sensuous description place and space, then, is a key ingredient in the recipe for an artful ethnography. In the art of ethnography it evokes the "there is."

\section{Dialogue in Artful Ethnography}

In artful writing what can be more difficult that crafting dialogue? The distinctive way that a person speaks is a window into her or his character, motivations, and emotional states. Important as it is, artful dialogue is often absent in ethnographic texts. "Informant" talk is often relegated to the indented block texts of transcribed interviews, which usually gives no indication of the idiosyncrasies of said "informant's" talk. In addition, "informant" talk is often transformed into indirect speech, in which the "informant's" talk is summarized in the ethnographer's explicative prose (Geertz, 1988). In artful ethnography, scholars borrow dialogue techniques from fiction and creative non-fiction writers who use them to convey important information and build character.

But is it possible to write dialogue that perfectly captures every aspect of a person's speech? I have found that crafting dialogue is the most challenging aspect of writing both fiction and ethnography. In my experience West Africans tend to speak to one another with a complex formality. Depending upon the time of day, there are multiple formal greetings. People often refer to one another indirectly - even in the context of the speech situation. Rather than calling one another by name, West African interlocuters often refrain from mentioning names. Instead they might refer to "the man from Bonfebba," or "the spirit priestess of Mehanna," or the "cousin of the blacksmith." To a reader in the US, UK, or France such expression may seem quite stilted. When I wrote my novel, The Sorcerer's Burden, I tried to replicate the formality of Songhay speech, which provoked the following response from a young hotshot literary agent in New York City.

[...] read much of your book, and I wanted to be in touch. Fact is, I think the idea, the setting, the story here is really awesome. Really interesting and different and intense. But if I'm honest, I think there are a few problems that became big issues for me. I think Omar's tone is meticulous and perfect, but he speaks in the same way he thinks, which is dry and lacking of emotion, and then, everyone else speaks in the same way, polite and careful and it feels like there's only one voice all the way through, which is pretty hard for me. If the dialogue 
had more spark to it, more interactiveness and individuality, I think this book could be really, really great. I know this is just me, others might think differently, but I'll tell you - I don't write comments like this unless I think there's merit. So I do wish you the best of luck, Paul (Author's Files).

Although I didn't appreciate his wet-behind-the ears arrogance, the comments convinced me to seek a middle-ground in my dialogue, which, in the end, made the novel more accessible to a broader audience of readers.

It is always good to read masterful dialogue. In what follows I present dialogue from Walter Mosely, a master of dialogue in fiction, Joshua Hammer, who presents memorable dialogue in creative non-fiction, and Ruth Behar, one of our finest ethnographers, who knows how to construct powerful dialogue.

Walter Mosley writes fabulous crime novels. His major protagonist who appears in many of his books is Easy Rawlins, an African American private detective who knows a thing or two because he's seen a thing or two. In Mosley novels the plots and characterizations are often articulated through dialogue. Here's a short example from his 2005 novel, Cinnamon Kiss, which features a conversation between Easy Rawlins and Cynthia Aubec:

"Hi. My names is Ezekiel Rawlins." I held out my hand.

A big grin came across her but somehow the mirth didn't make it to her eyes. She shook my hand.

"How can I help you?"

"I'm a private detective from down in L.A.," I said. "I've been hired to find a woman named Philomena Cargill... by her family."

"Cinnamon," the woman said without hesitation. "Axel's friend."

"That's Axel Bowers?"

"Yes. He's my partner here."

She looked around the storefront. I did too.

"Not a very lucrative business," I speculated.

The woman laughed. It was a real laugh.

"That depends on what you see as profit, Mr. Rawlins. Axel and I are committed to helping the poor people of society get a fair shake from the legal system.”

"You're both lawyers?"

"Yes," she said. "I got my degree from UCLA and Axel got his across the Bay in Berkeley. I worked for the state for a while but didn't feel very good about that. When Axel asked me to join him, I jumped at the chance."

“What's your name?" I asked.

"Oh. Excuse my manners. My name is Cynthia Aubec."

"French?" 
"I was born in Canada," she said. "Montreal” (2005: 87-88).

Notice how Mosely's dialogue contains both speech and descriptive action both of which lend themselves to the flow of the interaction.

The second example is a dialogue from Joshua Hammer's stunning work of creative non-fiction, The Bad-Ass Librarians of Timbuktu (2016), which describes how a Timbuktu guardian of his family's collection of ancient manuscripts saved those irreplaceable texts from the fires of radical Islamicists who had sacked and occupied his fabled city. Here is a conversation between Haidara, the aforementioned guardian and some Libyan officials, representing Muammar Al Qaddafi. After looking through the manuscripts the Libyan officials wanted to buy the collection.

"We have a proposition for you," they said.

"I'm listening," Haidara replied.

"We want to buy everything we see here." They opened a briefcase, and showed Haidara stacks of bills in various currencies"...

"Thanks, but no thanks," he told the Libyans. "You never said that you were coming here to attempt to purchase the manuscripts."

"What do you mean? We will pay you in any currency you want."

"It's not for sale."

"Why not?"

"Because this isn't for me. This is the heritage of Mali. It belongs to a great nation."

"But we can make you comfortable for the rest of your life."

“No," he said (2016: 50-51).

Here again, the dialogue underscores the rhythm of a tense interaction between Haidara, the central character of the work, and the cash-carrying Libyan officials.

The third example is from Ruth Behar's classic ethnographic memoir, The Vulnerable Observer (1996). The conversation is between Polonia, Rufi and Ruth Behar and takes place in rural Spain. The topic is how to shroud a cadaver.

Polonia began: "When it was my mother, we [she and her sister] shrouded her. And Junta. She died at night, at four, at three or so in the morning. We shrouded her between the three of us my sister Junta and I. Florencia [her brother-inlaw] was here, too, my husband was also here, which was curious, it was fiesta..."

Rufi interrupted her to ask a generalizing question. "But how did you wash them?"

Her mother shrugged. "You wash them."

"With a towel, a sponge?" 
"You wash them very well. No, nothing, it doesn't mean anything, because it is a normal body."

Rufi, playing the ethnographer, offers an explanation. "Why do you wash them, so that they will be clean when they go to heaven?” Rufi's zeal to interpret and draw conclusions - perhaps because it offers too close a mirror of me in ethnographic costume - makes me cringe in my seat.

"I don't know. These are customs."

Rufi turns to me and says: "It's folkloric, isn't it, Ruth?"

I, trying my best, intercept with a snatch of information I have picked up from an old will. "Yes, customs. Sometimes they dress them up in nun's or monk's clothes” (1996: 45-45).

In this short dialogue the reader not only learns something about mortuary customs in rural Spain, but also about the tangled complexities of the ethnographer's subject position in the field.

\section{Crafting Character in Artful Ethnography}

A central element of any artful ethnography is that of character. All too often the people in ethnographies remain obscure. What do they look like?

What physical features do they possess that distinguish them from other people? Might it be the way their faces are set in a frown, a grimace or a grin? Is their posture particular. Do they walk rapidly with a stifflegged gait or do they skip or limp? Are they unsteady on their feet?

Do they have a distinctive way of speaking? Do they repeat a phrase regularly, a phrase that is a window into their state of being? When readers have read an ethnographic text, will they remember the people describe in the book? In artful ethnography sensuously descriptive words evoke the idiosyncrasies of character to create an alluring and hard-to-forget portrait. I here present brief portraits from Michael Chabon's 1995 novel, Wonder Boys, from Anna Badkhen's ethnography of Fulani transhumance, Walking With Abel (2015), and from my own work-in-progress African Dreamscapes.

Here is a scene from Wonder Boys. Grady Tripp, a prodigy novelist, suffering from writer's block, goes to the airport to meet his famous literary agent Terry Crabtree.

“Tripp," said Crabtree, approaching me with his free hand extended. He reached up with both arms to embrace me and I held on to him for an extra second or two, tightly, trying to determine from the soundness of his ribs whether he loved me still. "Good to see you. How are you?" 
I let go of him and took a step backward. He wore the usual Crabtree expression of scorn, and his eyes were bright and hard, but he didn't look as though he were angry with me. He'd been letting his hair grow long as he got older, not, as is the case with some fashionable men in their forties, in compensation for any incipient baldness, but out of a vanity more pure and unchallengeable: he had beautiful hair, thick and chestnut-colored and falling in a flawless curtain to his shoulders. He was wearing a well-cut olive-drab belted raincoat over a handsome suit - an Italian number in a metallic silk that was green like the back of a dollar bill - a pair of woven leather loafers without socks, and round schoolboy spectacles I'd never seen before (1995: 7-8).

\section{In Walking With Abel, Anna Badkhen's describes Fanta, a rural Fulani woman in Mali.}

[...] Fanta nestled the calabashes on top of her hand and set off on the southbound path toward Wereka. She did no farewells; this was a ritual she performed every other day and it did not merit ceremony. Nor did she ease gradually into her walk. She started right out of the camp at a quick steady stride that never changed until she reached the village. It was the tempo of her last walk, and of her walks before that, and of her mother's, and of all the milkmaids' past recall who had fixed their footsteps to the trail before. She simply picked it up. She would have picked up a dropped calabash that way, or a grindstone she had loaned to a neighbor.

At first Fanta walked with her right hand raised to hold the straw lids so the wind wouldn't blow them away. After a hundred paces the arm and wrist drained of blood and began to ache. She stopped and shook off her right plastic flipflop and with her toes scooped up from the ground a flat stone. She flexed the right leg at the knee and stood on her left unbending leg and without leaning, without looking, reached behind her with her right arm and picked the stone out of her foot. Neck perfectly straight the calabashes steady on her head. She had done this a thousand times before. Her bubble-printed shawl flapped against her cheek. She placed the rock on the topmost lid and let both arms fall like a marionette's arms by her sides and walked again. Around her ankles night moisture rose cold from the drying fields. Pied crows hopped in low labyrinths of manure (2015: 49-50).

Finally, I provide a description of Amadu Zima, one of my Songhay mentors, who lived in the village of Mehanna, on the west bank of the Niger River.

One evening, like most of my evenings in Mehanna, I walked to Alfaggeh Adboulaye's study for more conversations about science, healing and religion. On the way I once again saw an old man standing by his compound door, which had been fashioned from a sheet of corrugated tin. As had been our practice, we exchanged warm greetings. This time, though, he waved for me to 
approach. It looked like he had once been a tall man. But age had bent him like a water-logged tree branch. Deep lines crisscrossed his square face. His eye whites, yellowed from years of exposure to dust and wind, teared with irritation. Even in that dire condition, his eyes suggested a deep kindness.

"You know I've been watching you."

"I didn't know. Watching me?"

"You've come here for many years."

"True."

"And each time you greeted me with kindness and respect."

I nodded.

"You never asked anything of me."

"True."

"I know your name, but you don't know mine."

A moment of silence filled the space between us.

"My name is Amadu Zima. I like you."

Not knowing what to say, I remained silent.

"Come into my house so I can tell you my story."

The old man invited me into his compound, which was barren - not a bush or tree growing, no chickens or sheep or goats - just sand, dirt, a few scattered tin bowls, a laundry tub, and an outdoor hearth, three blackened stones, forming a pyramid on top of which sat a large cast iron pot. There was one rectangular mudbrick house for the old man's wife and daughter, who weren't there. I followed the old man into his house, a conical hut with a mudbrick base covered by a thatch roof. The hut's thick walls kept it cool. Amadu Zima slept on a metal framed single bed with a straw mattress. We sat down on a frayed palm frond mat he had unrolled in the center of the hut. Smooth and clean wadi sand made the hut floor soft and cool.

In all three examples character is constructed through physical description of faces, movements, dress, speech and space. It is also constructed through what is said and unsaid, what is stated and what is left to the reader's imagination.

\section{The Art of Living in the World}

Whenever I visited Paris, I tried to sit in on screenings Jean Rouch's projection room, which was above his cluttered offices on the second floor of the Musée de L'Homme. When young filmmakers arranged to show Rouch, master documentarian, their unfinished films, he would routinely invite a motley assortment of people - scholars, other filmmakers, an occasional patron of the museum, and one or two students - to comment on the film-in-progress. 
“But I don't know anything about film, “one of the invitees once said at one of the screening sessions.

"That's good," Rouch replied. "It doesn't matter."

After the projection, Rouch, who always sat in the front row, turned around, faced his invitees and facilitated a discussion - impassioned debate on film technicalities, sound quality, editing techniques, and post-production problems. The person who had who had proclaimed her ignorance of film found the film "uninspiring."

Rouch then began to ask questions that I had heard before.

"Where is the story in this film?"

"How can you fix the story?"

"What can you do so that the film connects with the audience?" (Stoller, 2020).

For Jean Rouch story was always prior to theory. That is not to say that theories are not useful and important. They are. It is to say that in the world of science theories, given the instabilities of scientific truths, have short shelf lives. In the wake of erstwhile theories, though, we seem to always come back to the story, the foundation of the ethnographic record, which is the anthropological gift to the world. The narratives that comprise the ethnographic record are texts and films that can, if they are well crafted, remain open to the world. As Jean Rouch well knew, stories create a bond between the filmmaker and the audience or the author and her or his readers. Through the power of evocation stories can move us to think new thoughts, construct new realities and feel new feelings (Bruner, 1991). They are the catalyst for social change.

Story - sacred and profane - is perhaps the main cohering force in human life. A society is composed of fractious people with different personalities, goals, and agendas. What connects us beyond our kinship ties? Story... Story is the counterforce to social disorder, the tendency of things to fall apart. Story is the center without which the rest cannot hold (Gottschall, 2012: 138).

Indeed, stories are windows through which we encounter the human condition. They demonstrate how we are all connected. That is the power of the story. That is the work of art in ethnography.

So how do you learn to craft a good story?

Why are some films and/or ethnographic texts more memorable than others?

Merleau-Ponty and Michael Jackson might say that memorable ethnographies are the ones in which the sensuous projection of image - in 
prose and film - compels an audience to sense the drama of social life. Stories that poetically showcase the lived and un-lived environment, that feature idiosyncratic dialogue and that underscore the vulnerabilities of character have the capacity to create connections between authors and audiences. They have the capacity to remain "open to the world."

But in the art of ethnography, there is something more profoundly existential at play.

Songhay elders love to recite the following proverb:

Kumba hinka ga charotarey numey ("It takes two hands to nourish a friendship").

Indeed, the sensuous evocation of space, dialogue, and character present a necessary but not sufficient condition for crafting the kind of stories that comprise an artful ethnography. In the end, the artistic quality of ethnography devolves less from technique and more from how you live your life. Do you live in the moment? Do you walk with confidence on your path? Do you "open your ears" and listen to elders? Are you willing to enter the stressful arena of representational vulnerability? These life choices implicate ethnographers among their others and enable them to tell a good story. For me, the depth, texture and staying power of an ethnographic film or ethnographic text emerges directly from the depth of the relationships that the ethnographer has developed. No matter the sophistication of technical practice or philosophical nuance this deceptively simple principle sets the foundation for the future of an artful ethnography the insights of which chart a course for negotiating the existential and social turbulence of a troubled world. As scholars, is it not our obligation to artfully recount these insightful stories to sweeten the human condition?

It takes two hands to nourish a friendship.

\section{References}

Agee, J. and Evans, W. (1941). And Now Let Us Praise Famous Men. New York: Houghton Mifflin.

Badkhen, A. (2018). Fisherman's Blues: A West African Community at Sea. New York: Riverhead Books.

Badkhen, A. (2015). Walking with Abel. New York: Riverhead Books.

Behar, R. (1996). The Vulnerable Observer. Boston: Beacon Press.

Bruner, J. (1991). The Narrative Construction of Reality. Critical Inquiry, 18(1): 1-21.

Chabon, M. (1995). Wonder Boys. New York: Picador.

Charbonnier, G. (1959). Le Monologue du peintre. Paris: Julliard. 
Derrida, J. (1984). Deconstruction of the Other. Interview with Richard Kearney. In Dialogues With Contemporary Continental Thinkers: The Phenomenology of Heritage. R. Kearney, Ed. Manchester: Manchester University Press.

Durkheim, E. (1995) [1912]. The Elementary Forms of Religious Life London: Allen and Unwin.

Geertz, C. (1988). Works and Lives: The Anthropologist as Author. New York: Polity Press. Gottschall, J. (2012). The Storytelling Animal. New York: Houghton-Mifflin.

Hammer, J. (2016). The Bad-Ass Librarians of Timbuktu. New York: Simon and Shuster. Jackson, M.D. (2016a). As Wide as the World Is Wise: Reinventing Philosophical Anthropology. New York: Columbia University Press.

Jackson, M.D. (2016b). The Work of Art: Rethinking the Elementary Forms of Religious Life. New York: Columbia University Press.

Merleau-Ponty, M. (1969). La Prose du monde. Paris: Gallimard.

Merleau-Ponty, M. (1964). L'Oeil et l'esprit. Paris: Gallimard.

Mosley, W. (2005). Cinnamon Kiss. New York.

Nietzsche, F. (1956) [1876]. The Birth of Tragedy Out of the Spirit of Music. Garden City, NJ: Doubleday (Anchor Books).

Stoller, P. (2020). Conclusion: The World According to Rouch. In Routledge Handbook of Ethnographic Film and Video. P. Vannini, Ed. New York: Routledge.

Stoller, P. (2014). Yaya's Story: The Quest for Well Being in the World. Chicago: The University of Chicago Press.

Stoller, P. (2008). The Power of the Between: An Anthropological Odyssey. Chicago: The University of Chicago Press.

Stoller, P. (1989). Fusion of the Worlds: An Ethnography of Possession Among the Songhay of Niger. Chicago: The University of Chicago Press. 
